\section{Impact of marketization process on China's forestry economic growth - based on the statistical yearbook data from 1978 to 2016}

Impact of marketization process

\author{
Dan Qiao, Shuifa Ke, Xiaoxiao Zhang and Qiya Feng \\ School of Agricultural Economics and Rural Development, \\ Renmin University of China, Beijing, China
}

\begin{abstract}
Purpose - The paper aims to explore the impact of marketization on forestry economic growth. Firstly, the development process of forestry marketization was summarized. Secondly, from the three dimensions of forestry production factor marketization, production marketization and product marketization, the framework of marketization is constructed by the authors.

Design/methodology/approach - Based on the yearbook data from 1978 to 2016, the relationship between forestry marketization and forestry growth was demonstrated through multiple regression and Granger test in this paper.

Findings - The results showed that forestry marketization was one of the important driving factors that impacted on China's forestry economic growth. Since the reform and opening up, China's forestry marketization degree has been constantly strengthened, but there is still room for improvement. China has provided an important model as forestry marketization reform and development sample for the world.

Social implications - Many useful references and inspirations have been provided from China such as gradually promoting market-oriented reforms; paying attention to the important role of reform and opening up in the construction of market mechanism; dynamic coordination of market and government relations; developing and connecting the relationship between domestic and international market; and coordinating the development of forestry state-owned economy, private economy and mixed ownership economy.

Originality/value - This paper creates a measure index of forestry marketization from three dimensions of forestry production factor marketization, production marketization and product marketization.
\end{abstract}

Keywords Marketization, Forestry, Economic growth, Reform and opening up, Measure index

Paper type Research paper

\section{Introduction}

It is market economy that market mechanisms play the basic role in the allocation of social resources, and marketization is the process of transforming the resource allocation from planned adjustment to market regulation (North, 1990). As a progressive reform (Lin et al., 1993), China's marketization reform is a large-scale institutional change in the history of mankind (Gerard, 2004), making an outstanding contribution to China's rapid economic growth. However, there are constant controversies over the legitimacy of China's marketization and its impact on economic growth. Especially in recent years, the USA, Japan and some countries in the European Union announced that they denied China's market

(C) Dan Qiao, Shuifa Ke, Xiaoxiao Zhang and Qiya Feng. Published in Forestry Economics Review. Published by Emerald Publishing Limited. This article is published under the Creative Commons Attribution (CCBY 4.0) licence. Anyone may reproduce, distribute, translate and create derivative works of this article (for both commercial and non-commercial purposes), subject to full attribution to the original publication and authors. The full terms of this licence may be seen at http://creativecommons. org/licences/by/4.0/legalcode
Received 26 February 2020 Revised 19 May 2020 Accepted 17 October 2020 
FER

2,1

economy status. The battle on marketization status in China has been getting stronger. Cai and Treisman (2006) attributed the consistent growth of China's economy to the control of the central government and the competition of local interests rather than the driving role of marketization. The controversy stems from China's unique political system, which is different from the "endogenous" model of some western countries. As a "outsourced latecomer" developing country, it has gradually changed from a planning economic system to a planning and market coexistence economic system. As the saying goes, "all roads lead to Rome." Although there are differences in marketizations between China and developed countries, they also have some similar features.

As one of the most important basic industrial sectors, forestry has also made remarkable achievements during the past 40 years of reform and opening up. Nowadays, forestry was viewed as playing an important role in implementing sustainable development strategies, a leading role in ecological development, a basic role in the development of the western region and a special role in combating climate change. By the end of 2017, the total value of forestry industry had exceeded RMB7tn for the first time. Through the systematic review, some scholars found that the deepening of forestry marketization played a pivotal role in the rapid development of forestry economy (Xu and Hyde, 2019), and many rationalization policy recommendations directly targeting the problems were also proposed (Hyde and Yin, 2019; $\mathrm{Xu}$ et al., 2019). However, there are two main reasons for lack of empirical researches about the impact of forestry marketization on forestry economic growth. On the one hand, because market reform as an economic system reform policy is not a single change, it is difficult to measure the degree of market openness with a single or several variables for the reform of the intertwined relationships among the whole social environment, including economic development and social openness (Fan et al., 2011). On the other hand, as an industry that combines economic benefits, social benefits and ecological benefits, measurement of forestry marketization is more complicated.

\section{Literature review}

At present, many foreign scholars have carried out fruitful empirical analysis on the economic impact of market-oriented reforms. The research of Iradian (2009) shows that marketization has a significant positive impact on economic growth; De Melo et al. (2001) construct transformation indicators from three aspects: internal market, external market and privatization and find that institutional transformation has positive effects on economic growth; Selowsky and Martin (1997) consider this effect has a significant phase feature; in contrast, Merlevede (2003) used Eastern European countries as samples to find that the marketization process did not have a direct positive impact on national economic growth. Lin et al. (1993) believe that marketization is the main reason for the economic development gap between the eastern and Midwest regions. The empirical research analysis of Fan et al. (2011) and Wang and Tan (2005) shows that marketization mainly contributes to the economic growth through the path of factor allocation, price mechanism and product circulation. On the basis of measuring the marketization process of China's provinces in detail, Fan et al. (2003, 2011) calculated the marketization process's contribution to economic growth, which has reached an average of $1.45 \%$ per year. They proposed that marketization mainly plays a role by accelerating the circulation of factors and improving the efficiency of resource allocation. The continuous deepening of marketization promotes the free flow of information, clarifies the market price mechanism, enhances market transactions, reduces production efficiency and promotes economic growth by reducing the high cost of information (Lu and Zhu, 2016). In addition, the reduction of national economic intervention, the increase of enterprises' selfmanagement power, the flexible control of market supply and demand, the strategic production and operation the reduction of long-term transaction costs and the increase of 
economic profits further promote their technological innovation and economic growth. (Sun et al., 2005; Bennett et al., 2007). The international trade of products has broadened the product consumption market, promoted the local industrial chain, provided more jobs and promoted the rapid growth of the domestic economy (Wu, 2018).

Currently, China's forestry marketization research mainly learns from the agricultural marketization research, but there are few explicit measures or evaluations. Based on the micro and macro level of agricultural marketization, some scholars, from the perspective of agricultural marketization in a narrow sense, designed seven relevant indicators to evaluate the degree of agricultural marketization in China's transition period. China's agricultural marketization index was evaluated as 64.6\% (Chen and Chen, 1999). Learning from "marketization index method" and "economic freedom index method," Kong and Du (2010) designed an evaluation index of China's forestry marketization level consisting of five firstlevel indicators and 15 second-level indicators, with the characteristics of China's forestry. The system evaluates the level of marketization of forestry at the national and regional levels and its changing trends to conclude that different regions are at different levels of forestry marketization. In addition, Liao and Zhang (2014) used the panel data of 31 provinces (municipalities and autonomous regions) in China to establish a forestry marketization relative index system, which quantitatively proved that the forestry marketization process has a positive impact on farmers' income.

Western scholars generally believe that the marketization approach has always been an important means to achieve the rational allocation of forest resources and other production factors. The researches on forestry marketization mainly focus on two aspects, one is from the perspective of market failure; the other is the profitability perspective under normal market operating conditions. Most foreign studies have shown that forestry is profitable, and it is proved that large-scale forest production is conducive to the acquisition of profits. This means that the management of forest resources must be multi-purpose utilization, which is the characteristic of modern forestry marketization (Du, 2009). Some scholars in China have studied the marketization of forestry. Most scholars are discussing social forestry development and marketization further strengthen the effect on forestry economic growth during the promotion of forestry marketization. Xu (2012) proposed to adopt targeted countermeasures to realize the market-oriented reform of forestry and to realize the effective use of forestry resources, which is needed for modern socialist construction and China's ecological environment protection. Kong and Liao (2013) used the annual forest marketization data of 31 provinces (autonomous regions and municipalities) in China to empirically analyze the forestry economic growth effect of forestry marketization. The result shows that the degree of forestry marketization has a significant positive impact on forestry economic growth, the pace of China's forestry marketization is relatively slow and the transformation task of forestry marketization is still very arduous. Fan (2017) believed that there are mutually reinforcing relationships between the openness of forestry marketization and the growth of forestry economy. Sun and Li (2014) and Zhou et al. (2016) believed that forestry marketization is also an inevitable requirement for promoting the sound and rapid development of the forestry economy. Zhuang (2016) regarded the process of forestry marketization as one of the important factors and analyzed the effects of forestry economic growth. She pointed out that government, land, science, technology and other factors have driven the rapid development of forestry economy.

In general, China's research on forestry marketization is not perfect, and there is still much room for research. Previous studies have focused on descriptive research on the marketization of forestry in China. Some existing researches on the degree of forestry marketization have provided useful references for this study. However, in terms of researches on the forestry marketization index system constructed by predecessor, international trade factors have not been considered, and the time dimension of data for the empirical research

\section{Impact of marketization process}


FER

2,1

was mostly short. There is still a lack of systematic measurement on the process of forestry marketization since the reform and opening up. Therefore, this paper aims to use the timeseries data since 1978 to establish a forestry marketization evaluation index system from multiple dimensions and measure the impact of forestry marketization process on forestry economic growth. We look forward to providing a useful reference on forest market reform for other developing countries.

\subsection{Development process of China's forestry marketization}

Since the reform and opening up in 1978, China has actively explored the reform of the socialist market economic system with Chinese characteristics and has continuously deepened the market-oriented reforms in the commodity sector and production factors. More than $97 \%$ of the prices of goods and services have been adjusted by the market. The market mechanism is basically established, and the market for production factors, such as capital, is from sprouting to accelerating development to promote economic innovation and competitiveness. In addition, the non-public economy has become an indispensable force for China's development. Compared with 1980, China's export commodity structure, foreign trade business entities, international market layout and trade methods have been optimized to achieve great-leap-forward development. From US\$980m in foreign investment in 1983 to US\$136.3bn in 2017, the scale and quality of China's use of foreign capital are constantly improved. Since the reform and opening up in 1978, China's marketization process has been divided into three stages: the early stage of reform and opening up (1978-1992), the initial establishment of the socialist market economic system (1993-2003) and the acceleration of perfecting the socialist market economic system (2003-present). As an important part of the marketization process, forestry marketization has also experienced a corresponding development process, which includes the following three stages:

The first phase from 1978 to 1992 was the initial stage of the forestry marketization system. In the initial stage of China's market system construction from 1978 to 1992, China launched a household contract responsibility system in rural areas and gradually liberalized small commodity market. In 1981, the government document "Decision on Protecting Forest Development Forestry Issues" was issued, marking the change of the traditional forestry system in China, which enabled China to enter a diversified development path. With the reform of the economic system in 1984, China proposed the development of a planned commodity economy. In 1985, the policy of "three determination on forestry" was established, which aimed to stabilize the mountain rights and forest rights, delineate the ownership of private mountain and determine the forestry production responsibility system. This policy broke the original tenure system that is completely state ownership. Since 1985, China's collective forest areas have begun to cancel the unified purchase and sale system on timer and open up the timber market so that collective timber can be listed freely on the market, and it could be purchased and sold on negotiation. In 1987, the decision on "strengthening the establishment and cultivation of a socialist market system" is clearly made in the Thirteenth National Congress of the Communist Party of China. China accelerated the pace of opening up on price regulation. In 1992, the party's "14th National Congress" proposed to play a fundamental role in the allocation of resources by the market mechanism and promulgated a new "price management catalogue" to significantly reduce the centrally managed price items.

The second phase from 1993 to 2002 established and accelerated the development of the forestry marketization system. After adopting the "Decision of the Central Committee of the Communist Party of China on Several Issues Concerning the Establishment of a Socialist Market Economic System” in 1993, which established the basic framework of the socialist market economic system, which encourages continuously promoting the marketization of production factors and reducing government intervention. In the same year, the forest price 
system was fully implemented, the management system of forestry funds was reformed and China's first national timber and forest products trading market was established in Beijing, which promoted the marketization of forestry products. In 1994, the dual-track system for industrial production materials prices was basically canceled. In the same year, the reforms on classifying management of state-owned forest farms and optimizing industrial structure were carried out. In 1995, the public document "Outline of Reform on Forestry Economic System" was introduced to allow the use rights of the "four barrenness" to be bought and sold and allow forest assets to be realized through tendering, auction, leasing and mortgage. The "Law of the People's Republic of China on Forest" stipulates that the use right of forests, trees and woodland can be transferred. In 1998, the "Price Law of the People's Republic of China" proposed to implement and improve the mechanism, which ensures that the market plays a main role in forming prices. In 1999, the "Notice on Forestry Taxation Issues" was issued, which clearly stipulated that some enterprises are exempt from income tax. The 15th National Congress of the Communist Party of China proposed that China's basic economic system is that public ownership is the mainstay, and diverse forms of ownership are joint development. In 1999, non-public ownership economy was clarified as an important part of the socialist market economy. In the same year, the "Administrative Measures for the Pilot Export of Sawn Timber Processed by Imported Log" and the "Guiding Opinions of the State Forestry Administration on Strengthening the Scientific and Technological Support for Key Forestry Construction Projects" were issued, which emphasize the importance of export and technology elements in the development of forestry. After China joined the World Trade Organization (WTO) in 2001, the State Forestry Administration formally established the China forest certification work leading group to promote the export of forest products. The reform of the collective forest rights system in the 1990s further promoted the marketization of forestry, which standardized the transfer mechanism on forestland and forest and exerted the various functions of the market in the allocation of forestry production factors to promote the modern development of forestry.

The third stage from 2003 to present is a period of deepening and improving the forestry marketization system. The role of market factors in the operation of the national economy has grown from weak to strong, and the market has been embedded from the initial market factors to the establishment of the overall system. At present, the market has initially established a complete form that is capable of resource allocation and has begun to play an independent role in resource allocation. The adoption of the "Decision on Improving Several Issues Concerning the Socialist Market Economy" in 2003 required the establishment of a sound socialist market economic system, deepening the reform of the economic system and promoting the all-round economic and social development, which marked a new stage in China's market-oriented development. In 2007, the 17th National Congress of the Communist Party of China proposed to give full play to the basic role of the market in resource allocation. These actions all reflected the obvious trend of "strong market, weak government." At the same time, China mainly focused on financial investment, strengthening the input on science and technology and developing non-public economy. Some documents have been successively issued, such as the "Several Opinions of the State Council on Encouraging Support and Guidance for the Development of Non-Public Economy including the Individual and Private Sectors" and the "Several Opinions of the State Council on Encouraging and Guiding Several Opinions on the Healthy Development of Private Investment." The Third Plenary Session of the 18th Central Committee of the Communist Party of China proposed to comprehensively deepen reforms through three ways: promote economic, political, cultural, social and ecological civilization reforms; encourage, support and guide the development of non-public ownership economies; and ensure the market plays a decisive role in resource allocation. In 2015, the "Opinions on the Development of a Mixed-Ownership Economy for State-Owned Enterprises” was issued, which

\section{Impact of marketization process}


FER

2,1

put forward the steady advancement of mixed-ownership economic practices. In 2016, the "Opinions of the CPC Central Committee and the State Council on Improving the Property Rights Protection System to Protect Property Rights According to Law" was promulgated. Then, in 2017, relevant regulations to promote the long-term development strategy of small and medium-sized enterprises were introduced, including the "Guiding Opinions on Accelerating the Cultivation of New Forestry Management entities." In 2003, the "Decision on Accelerating Forestry Development" was adopted in China. Then, in 2008, the "Opinions on Comprehensively Promoting the Reform of Collective Forest Property Right System" was promulgated, which aims to transform the forestry production relationship, activate market productivity through the property rights reform, achieve the goal of clear property rights, liberalize management rights, implement disposal rights and clarify income rights. Since China joined the WTO, the forest products trade has become more liberalized, import tariffs have been greatly reduced and non-tariff barriers to forest products have been eliminated. On November 23, 2009, the China Forestry Property Exchange was established in Beijing. At present, China has established a number of large-scale forest rights exchanges such as the East China Forest Exchange, the Southern Forest Exchange and the Central Forestry Property Exchange, which provide bulk spot trading, forestry property rights trading, forestry carbon trading and forest tenure mortgage loans. In addition, China actively cultivates new types of forestry management entities. By the end of 2016, the number of new types of forestry management entities had reached 231,500, and the area of forestry management reached 529 million mu. In 2018, there were 348 national forestry professional cooperatives' demonstration cooperatives and 439 national-level farmers' forestry cooperatives. Since the reform and opening up, in addition to the deepening of the marketization of the property rights system, another manifestation is the use of China's forestry funds, especially in foreign capital, which has formed an all-round, multi-level, wide-area open pattern (Song, 2014). In 2016, the National Development and Reform Commission recently issued the "Guiding Opinions on Promoting Forestry Construction by means of Public-Private-Partnership (PPP)". The implementation of forestry PPP has broadened China's forestry financing channels and became a new lever to incite the new development of Chinese forestry market.

In summary, China's market mechanism has undergone three major processes: fostering market mechanisms, comprehensively establishing market mechanisms and deeply perfecting market mechanisms. China's forestry marketization is developing in parallel with the marketization process of the whole country. China's forestry marketization policy tends to continue to strengthen over time, from the recognition to the establishment of market mechanisms, and then to fully play the role and mainly rely on market mechanisms. China's market-oriented system reform will inevitably have a corresponding impact on the development of forestry economy. In the early days of reform and opening up, forestry took the lead in promoting price marketization. After the establishment of the socialist market system, the forestry sector followed the national policy trend and further promoted the marketization of factors. After China's accession to the WTO, the pace of forest certification accelerated, which promoted the international marketization of products. During the period of deeply improving the market system, the non-public ownership economy is booming, the main entities of new forestry management are growing, the government is decentralized, the administrative intervention is reduced, so that the market mechanism is continuously strengthened.

\section{Establishment of forestry marketization measurement index system \\ 3.1 Index of forestry marketization measurement}

Regarding to the concept of marketization, China and west have different views. Fan et al. (2003) point that marketization has special characteristics of the times and regional characteristics. This paper defines the forestry marketization as the forestry resources is 
more and more allocated by the market mechanism over time, with the process from the planned economy to the market economy until the forestry economic activities fully follow the rule of the market. Ultimately, the dependence of forestry on market mechanisms is constantly deepening and improving.

As a complex ecosystem, forestry is also a complex transformation process of input to output. Based on the research by $\mathrm{Lu}$ and $\mathrm{Hu}$ (1993), Chang and Gao (1998) and Fan et al. (2003), this paper integrates Zeng (2003) global trade perspective to construct a new forestry marketization evaluation system with three dimensions, which includes forestry factor marketization, forestry production marketization and forestry product marketization (Figure 1). The factor marketization is the core content of the marketization process (Chang and Gao, 1998). The input of forestry labor, technology and capital are important indicators to reflect the development process of marketization (Sun and Li, 2014). In addition, the input of foreign capital on China's forestry is diversified from initial nothing. Therefore, to explore the degree of opening up, the capital elements are divided into domestic and foreign sources. Forestry production and management can be measured from two aspects: the main entities of forestry management and the behavior of production and management. At present, China is still in a critical period of deepening the market economic system. The non-public economy is an important foundation for stabilizing the economy. Thus, non-state-owned economic enterprises and new forestry cooperative entities are used to reflect the process of marketization in forestry sector. The proportion of non-forestry industry output value in the forestry output is used to measure the impact by market mechanisms. and the degree of marketization of forest products is measured from both domestic and overseas consumption.

The selection of indicators is mainly based on the framework shown in Figure 1, and the availability and usability of the data are also considered. As the ideal indicators of the new forestry production and operation entities cannot obtain continuous data, the substitution

\section{Impact of marketization process}

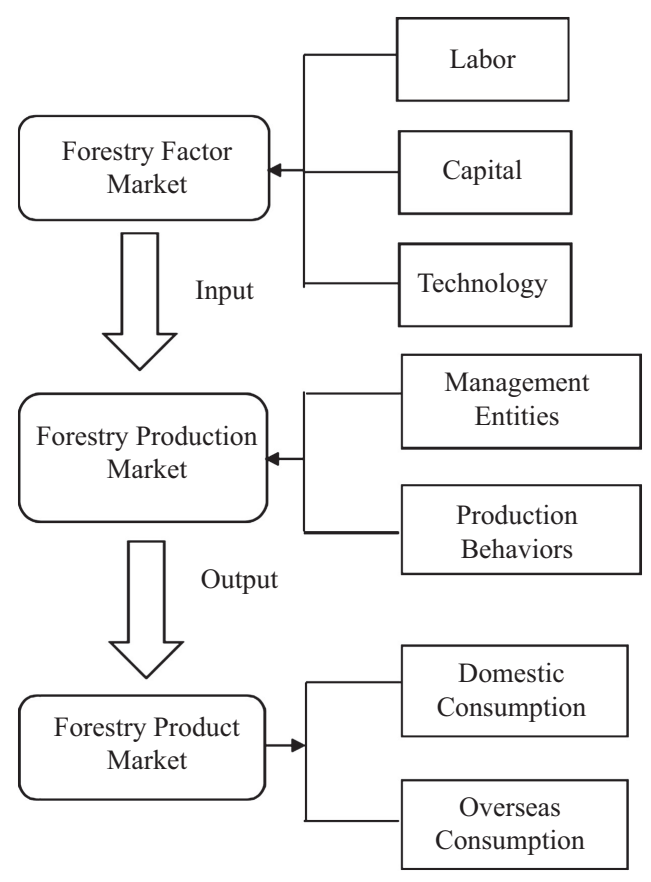

Figure 1.

Forestry marketization analysis framework 
FER

2,1

50

indicators are the proportion of forestry system enterprises and institutions at the end of the year. In the end, this paper selects the marketization of forestry factors (forestry labor marketization, forestry technology-level marketization, forestry capital marketization), forestry production marketization (forestry management entities marketization, forestry production behaviors marketization), forestry product marketization (domestic circulation marketization, international trade) as an indicator for measurement accounting. The specific indicators are listed in Table 1. Due to the actual availability of data, the statistics of forestry indicators in 1978 were inconsistent, so the data were mainly derived from 1978 to 2016 of the China Forestry Statistical Yearbook and the China Rural Statistical Yearbook.

\subsection{Establishment of the indicator system method}

This paper intends to use the entropy method to establish the indicators system of forestry marketization. The entropy is a thermodynamic noun, which is used to indicate the disorder of the system. Later, it has been widely applied in many disciplines (Zhou et al., 2016). Index weights can be determined based on the external objective raw information (Shu et al., 2015) and are widely used in industrial assessment and calculation.

First, the standardization of the indicators is required, and the initial matrix can be obtained from all the data as follows, $X=\left(x_{i j}\right) n m, i=1,2, \ldots, n ; j=1,2, \ldots, m, n$ refers to the year, $m$ refers to the number of indicators, $X_{i j}$ represents the $j$ th indicator value of the $i$ th year. The indicators in this paper are positive, so the standardization formula is as follows:

$$
y_{i j}=\frac{x_{i j}-x_{j \min }}{x_{j \max }-x_{j \min }}
$$

$X_{j \min }$ and $x_{j \max }$ represent the minimum and maximum values in the $j$ th indicator, respectively. As the value will be 0 after the formula is calculated, this paper will do translational processing on all the indicators to facilitate subsequent calculations:

$$
y_{i j}^{\prime}=y_{i j}+0.01
$$

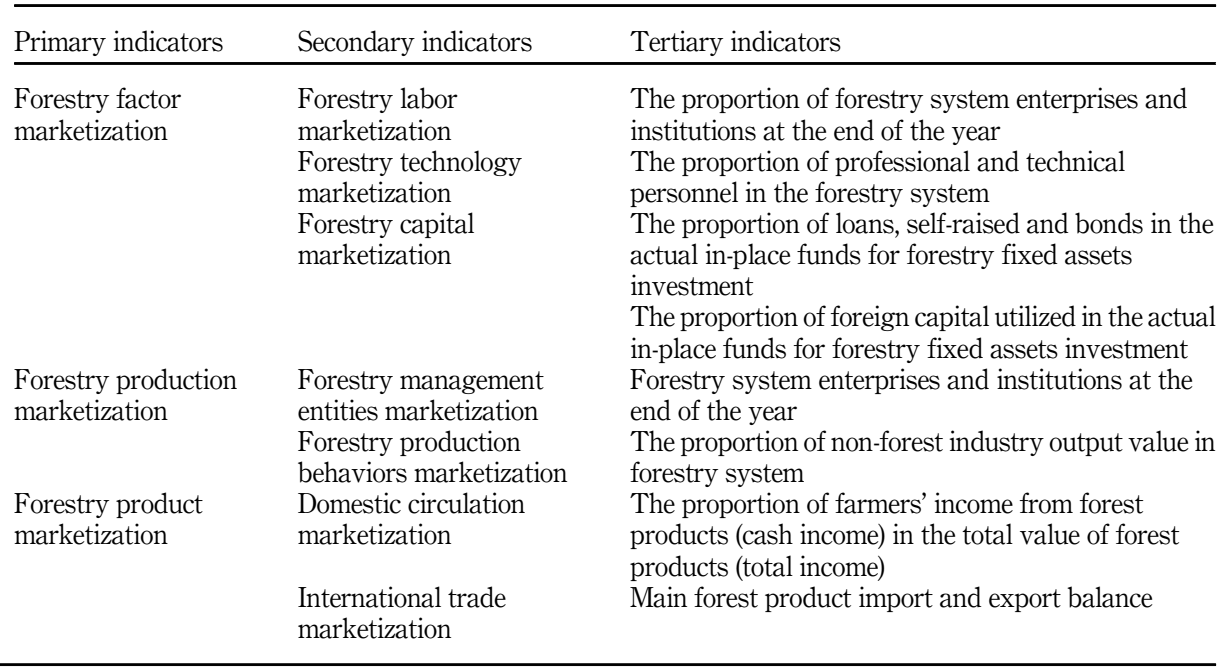

Table 1.

Forest marketization measurement indicators entities marketization Forestry production marketization marketization
The proportion of forestry system enterprises and personnel in the forestry system actual in-place funds for forestry fixed assets investment in-place funds for forestry fixed assets investment Finstry system enterprises and institutions at the of the year forestry system products (total income) Main forest product import and export balance


Secondly, the entropy value is calculated from the dimensionless data, and the upper entropy value $E$ corresponding to the $j$ th indicator in the industry is: $E_{j}=-k \sum_{i=1}^{n}\left(p_{i j} \times \ln p_{i j}\right)$ where $k=-\frac{1}{n m}, p_{i j}=\frac{y_{i j}^{\prime}}{\sum_{i=1}^{n} y_{i j}^{\prime}}$

\section{Impact of marketization process}

Finally, the weight $w_{i j}$ of the $j$ is obtained as $w_{i j}=\frac{1-E_{j}}{m-\sum_{j=1}^{m} E j}$

Thus, the forestry marketization index is $u_{i}=\sum_{j=1}^{m} w_{i j} x_{i j}, \sum_{j=1}^{m} w_{i j}=1$.

\subsection{China's forestry marketization index}

It can be seen from Figure 2 that the evaluation value of China's forestry marketization indicators has shown volatility since 1978 . China's forestry marketization index is about 0.18 in 1978, and increased to 0.71 in 2016. In the early stage of reform and opening up, due to the particularity of the forestry industry, there is a lag, so the process of forestry marketization is relatively flat. In 1986, there was a relatively rapid increase because of the impact from the policy "three determination on forestry." In 2008, because of China's new round of forest tenure reform, the process of forestry marketization has generally entered a state of continuous growth, and the growth rate of index became faster in recent years.

Figure 3 reflects the changes in the marketization index of forestry factor, forestry production and forestry product from 1978 to 2016. It can be seen from Figure 3 that the three indices are all raising. At the beginning of reform and opening up, the marketization index of forestry elements was the highest, and the marketization index of forest products was the highest in 2016. Since the initial establishment of the market economic system in 1993, the forestry marketization index has gradually increased. While may mainly be affected by the Asian financial crisis, the index tends to decline. The marketization of forest products is the fastest among these three indicators, especially after 2002. This has a great relationship with China's accession to the WTO in 2001. This accelerates the process of market opening, and the internationalization of forest products trade has become more apparent. However, the indicator has declined in 2016, which is influenced by political controversy and international trade disputes. The marketization of forestry production is relatively slow in the first 30 years. Since China's new round of forest tenure reform started in 2008, the marketization trend of forestry production is obviously enhanced, includes the forestry production factor, the cultivation of new forestry management entities and the business operations behavior.

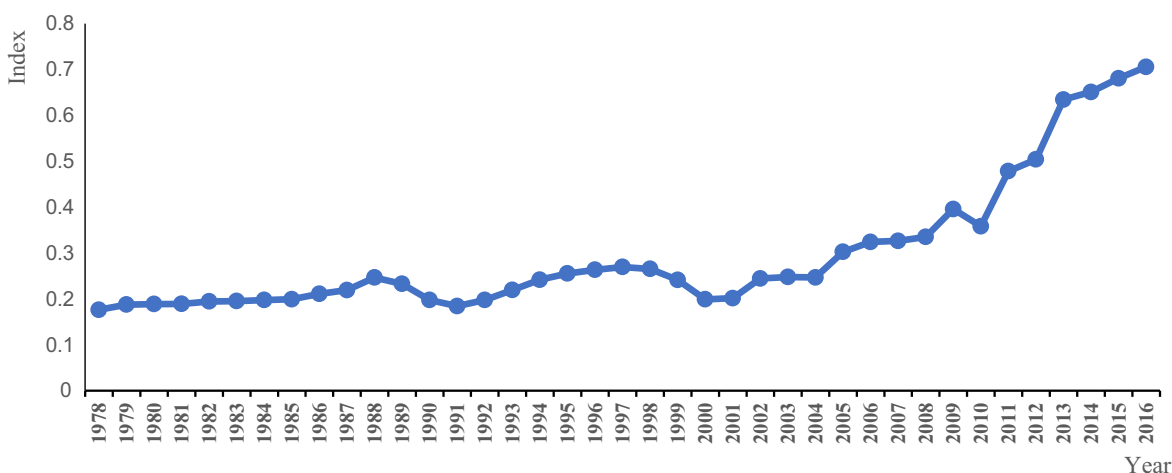

Figure 2.

China forestry marketization index $1978-2016$ 
FER

2,1

52

Table 2 reflects the mean, standard deviation, maximum and minimum values of the index of forestry marketization, factor marketization, production marketization and product marketization in China. From Table2, we can see that China's forestry marketization index has also increased with the continuous improvement of the socialist market economic system. It has increased from 0.2 in 1978 to 0.44 in 2016. Besides, the index tended to stabilize with the standard deviation reduced from 0.19 to 0.17 . With the development of the socialist market economic system, all of the tendencies of the three indices are basically consistent, they have increased $0.15,0.35$ and 0.41 , respectively. With the continuous advancement of reform and opening up, the reform of China's socialist market economic system has deepened, and the degree of forestry marketization has also been continuously improved. More details can be seen from Table 2.

\section{Method}

\subsubsection{Model}

Although market-oriented reforms have been confirmed by most scholars to have a positive effect on economic growth (Fan et al., 2011; Wang and Fan, 2007), marketization is not the only driving force for China's economic growth. The inputs of labor, capital, technology and other factors are also should be concerned (Shi and Wang, 2016). To comprehensively analyze the driving force for promoting economic growth, this paper integrates the neoclassical economic growth theory, Cobb-Douglas production function and Denison economic growth factor theory. Besides the factor of marketization being considered, forestry capital investment $(K)$, forestry labor input $(L)$, forest land input $(S)$ and forestry science and technology progress factors (a) are also added to this study. We build the following production function that includes the marketization:

$$
y=f(K, L, S, a, \text { market })
$$

logarithm to this function:

$$
\ln y=\beta_{0}+\beta_{1} \text { market }+\beta_{2} K+\beta_{3} L+\beta_{4} s+\beta_{5} L a+\varepsilon
$$

As this paper focuses on the impact of forestry marketization on China's forestry economic growth, forestry capital input $(K)$, forestry labor input $(L)$, forest land input $(S)$ and forestry technology progress factors (a) are used as control variables to establish the least squares ordinary least squares (OLS) measurement model as follows:

$$
\ln y=\beta_{0}+\beta_{1} \ln \text { market }+\sum \beta_{2} \ln x+\varepsilon
$$

Figure 3.

Changes in the marketization index of forestry factor, production and products from 1978 to 2016 


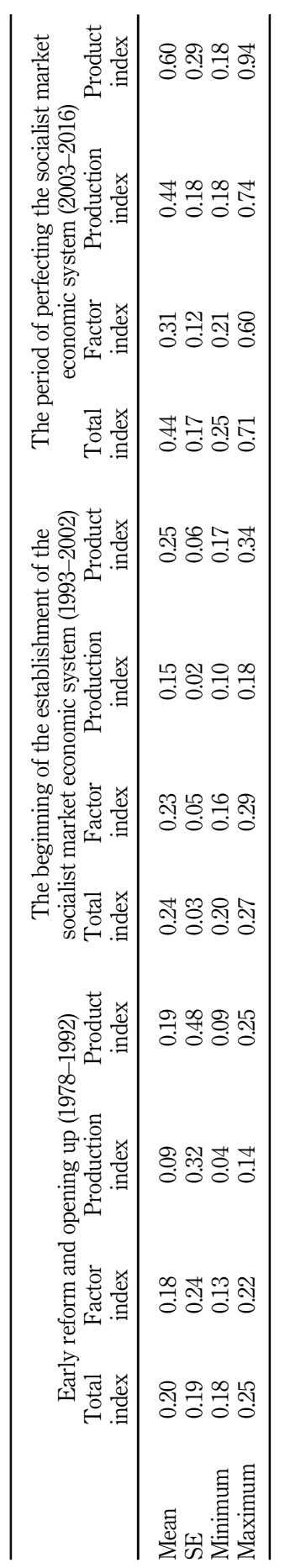

Impact of marketization

process

53

Table 2. Descriptive statistics of forestry marketization index 
FER

2,1

54

In the regression model, $y$ represents the total forest output value, market represents the forest marketization index of the year, $x$ represents a series of control variables, including forestry capital investment $(K)$, forestry labor input $(L)$, forest land input $(S)$ and forestry technology $(a) ; \varepsilon$ is the error term.

\subsection{Variable selection and data sources}

In this study, the total forestry output value $(y)$ is selected, as the dependent variable to reflect the situation of forestry economic growth. The value is calculated by dividing the retail price index of commodities based on 1978. Data for research came from "China Forestry Statistical Yearbook", "China Statistical Yearbook" and "China Forestry Yearbook” from 1978 to 2016.

The core independent variable is the forestry marketization index of 1978-2016. It is calculated by the entropy method as mentioned above.

In terms of control variables, the main considerations are as follows: (1) forest industry fixed assets investment by the end of the year is selected to represent the capital investment $(K)$, it can be calculated by forestry fixed assets investment divided by price index of investment in fixed assets to exclude the impact of price factors. (2) Because there are no statistical indicators and annual data of national forestry labor, the paper selects the number of employees in forestry sector over the years as the measurement index of labor input $(L)$. (3) This paper selects afforestation area $(S)$ as the measurement index of forest land input. Forest resources are sorted out every five years in China due to the lack of continuous forest area. (4) Technologies' progress contribution rate $(a)$ is selected as the measurement index of technologies progress level by using the Solow residual method (Table 3).

\subsection{Regression analysis}

To explore the extent of the above factors affecting forestry economic growth, this paper uses Stata14.0 to do the model regression. The regression result smoothly passed the robustness test. The goodness-of-fit $R^{2}$ is 0.85 . The specific results are shown in Table 4.

The result could be drawn that the forestry marketization index has a very significant positive relationship with the total forestry output value (at a significant level of $1 \%$ ), and its output elasticity is up to 7.60. This shows that as China's forestry marketization process continues to deepen, it can increase China's total forestry output value and promote the growth of forestry economy, which is consistent with the conclusion of Kong and Liao (2013).

Among the control variables, forestry capital investment and forestry technology progress are positively related to total forestry output value at $5 \%$ level, which is consistent with the research did by Ke et al., in 2014, and its output elasticity is 0.32 and 0.15 , respectively. Labor input has a negative correlation with the total output value of forestry, which is consistent with the opinions of Fan et al. (2011). The forest land input is positively related to the total forestry output value at the $10 \%$ level, and its output elasticity is 0.30 . As can be seen from Table 4, forestry capital investment, forestry resource input and forestry science and technology progress are also important factors that affect the increase of total forestry output value.

\subsection{Granger causality test}

To further verify the relationship between forestry marketization and forestry economic growth, we do another analysis. Based on the time-series data from 1978 to 2016, this paper first does logarithm of treatment on the data and performs unit root test, and then performs first-order difference. Although $\ln Y$, market, produce and production have unit roots existing in non-stationary series initially, the significances are changed to below $1 \%$ after first-order difference processing. The sequences after the difference already became to be stationary. The results on specific unit root test are shown in Table 5. 


\begin{tabular}{|c|c|c|c|c|}
\hline Year & Forestry output growth rate & Technology growth rate & The contribution of technological progress & $\begin{array}{l}\text { Impact of } \\
\text { marketization }\end{array}$ \\
\hline 1978 & 0.069 & 0.138 & 2.009 & process \\
\hline 1979 & 0.087 & 0.107 & 1.23 & \\
\hline 1980 & -0.043 & -0.059 & 1.376 & \\
\hline 1981 & 0.197 & 0.212 & 1.078 & \\
\hline 1982 & 0.084 & 0.092 & 1.093 & \\
\hline 1983 & 0.039 & 0.036 & 0.933 & 55 \\
\hline 1984 & 0.094 & 0.091 & 0.976 & \\
\hline 1985 & -0.025 & -0.015 & 0.611 & \\
\hline 1986 & -0.502 & -0.498 & 0.991 & \\
\hline 1987 & 0.576 & 0.589 & 1.023 & \\
\hline 1988 & -0.523 & -0.497 & 0.951 & \\
\hline 1989 & -0.149 & -0.136 & 0.914 & \\
\hline 1990 & 1.755 & 1.749 & 0.997 & \\
\hline 1991 & 0.070 & 0.073 & 1.055 & \\
\hline 1992 & 0.096 & 0.086 & 0.896 & \\
\hline 1993 & 0.710 & 0.711 & 1.002 & \\
\hline 1994 & 0.105 & 0.209 & 1.998 & \\
\hline 1995 & 0.027 & 0.013 & 0.494 & \\
\hline 1996 & 0.021 & 0.017 & 0.856 & \\
\hline 1997 & 0.114 & 0.079 & 0.687 & \\
\hline 1998 & 0.460 & 0.361 & 0.783 & \\
\hline 1999 & 0.205 & 0.152 & 0.743 & \\
\hline 2000 & 0.132 & 0.047 & 0.361 & \\
\hline 2001 & 0.160 & 0.109 & 0.689 & \\
\hline 2002 & 0.148 & 0.090 & 0.611 & \\
\hline 2003 & 0.266 & 0.227 & 0.854 & \\
\hline 2004 & 0.144 & 0.132 & 0.912 & \\
\hline 2005 & 0.217 & 0.195 & 0.898 & \\
\hline 2006 & 0.247 & 0.232 & 0.943 & \\
\hline 2007 & 0.133 & 0.116 & 0.871 & \\
\hline 2008 & 0.085 & 0.047 & 0.552 & \\
\hline 2009 & 0.229 & 0.199 & 0.870 & \\
\hline 2010 & 0.263 & 0.271 & 1.029 & \\
\hline 2011 & 0.280 & 0.338 & 1.207 & \\
\hline 2012 & 0.264 & 0.305 & 1.156 & \\
\hline 2013 & 0.183 & 0.163 & 0.890 & \\
\hline 2014 & 0.131 & 0.125 & 0.957 & \\
\hline 2015 & 0.098 & 0.081 & 0.835 & \\
\hline 2016 & 0.127 & 0.116 & 2.008 & ition rate of \\
\hline \multicolumn{5}{|c|}{$\begin{array}{l}\text { Note(s): Solow remainder method. } \frac{\Delta A}{A}=\frac{\Delta Y}{Y}-\alpha \frac{\Delta K}{K}-\beta \frac{\Delta L}{L} \text {, where } \frac{\Delta Y}{Y}, \frac{\Delta K}{K}, \frac{\Delta L}{L} \text { refer to the growth rate of } \\
\text { forestry output value, the fixed asset investment and the forestry employee, respectively. And, the two elastic } \\
\text { coefficients estimated by least squares regression will be used to calculate }(\alpha=2.395208, \beta=5.306585) \text {. }\end{array}$} \\
\hline
\end{tabular}

In this paper, the optimal lag order is determined according to LL, LR, df, $p$, FPE, AIC, HQIC, SBIC indicators. The optimal number of stages is determined to be first order based on the test results in Table 6. As can be seen from Table 7, there is no cointegration relationship for these time-series data. Finally, to explore whether there is a causal relationship between the overall marketization of forestry economic growth and forestry total marketization, the marketization of forestry factors, forestry production and the forestry products, Granger causality test was carried out. According to the different stages of the reform and opening up and the market economic system, this paper conducts Granger tests on three different stages. The specific results are shown in Table 6. 
FER

2,1
Variable name

Core independent variable

Forestry factor marketization

Forestry production marketization

Forestry products marketization

\section{Control variables}

Forestry capital investment $(K)$

Forestry labor input $(L)$

Forest land input (S)

Forestry technology progress factors $(a)$

Constant

Number

Table 4.

$R^{2}$

Regression results

Note(s): Standard errors in parentheses; ${ }^{* * *} p ;<0.01,{ }^{* *} p<0.05, * p<0.1$

Forestry output value

$1.504 * * *(0.476)$

$0.137 * *(0.0546)$

$0.214 * *(0.0936)$

$0.269 * *(0.120)$

$-1.223(0.833)$

$0.137(0.290)$

$0.000741(0.00360)$

$4.951 *(2.537)$

39

0.863

\begin{tabular}{lrrrr}
\hline Variable & Coefficient & $T$ & $p$ & Result \\
\hline $\ln Y$ & 0.046 & 1.19 & 0.241 & 非平稳 \\
Market & 0.062 & 0.99 & 0.328 & 非本稳 \\
Factor & -0.630 & -3.29 & 0.002 & 平稳 \\
Produce & -0.103 & -0.98 & 0.335 & 非平稳 \\
Production & 0.023 & 0.62 & 0.542 & 非本稳 \\
Dln $Y$ & -1.195 & -5.98 & 0.000 & 平稳 \\
Dmarket & -1.191 & -6.69 & 0.000 & 平稳 \\
Dproduce & -1.457 & -9.20 & 0.000 & 平稳 \\
Dproduction & -0.630 & -3.90 & 0.000 & 平稳 \\
\hline
\end{tabular}

Table 5.

Results on sequence unit root test

\begin{tabular}{lcccccccc}
\hline Lag & LL & LR & df & $p$ & FPE & AIC & HQIC & SBIC \\
\hline 0 & 233.442 & & & & $9.1 \mathrm{e}-14$ & -12.9967 & -12.9046 & -12.73 \\
1 & 371.617 & 276.35 & 36 & 0.000 & $2.8 \mathrm{e}-16^{*}$ & -18.8353 & $-18.191^{*}$ & $-16.969^{*}$ \\
2 & 406.151 & 69.068 & 36 & 0.001 & $3.6 \mathrm{e}-16$ & -18.7515 & -17.555 & -15.2853 \\
3 & 448.458 & 84.612 & 36 & 0.000 & $4.4 \mathrm{e}-16$ & -19.1119 & -17.3631 & -14.0459 \\
4 & 504.146 & $111.38^{*}$ & 36 & 0.000 & $5.8 \mathrm{e}-16$ & $-20.237^{*}$ & -17.9359 & -13.5711 \\
\hline
\end{tabular}

Table 6.

Results on sequence optimal lag-order test

\begin{tabular}{lccc}
\hline $\mathrm{H}_{0}$ & Eigenvalues & Trace statistic & $5 \%$ critical value \\
\hline 0 & - & $91.0605^{*}$ & 104.94 \\
1 & 0.57482 & 59.4163 & 77.74 \\
2 & 0.53054 & 31.4377 & 54.64 \\
\hline
\end{tabular}

It can be seen from Table 8 that forestry marketization is the Granger cause of forestry economic growth since the reform and opening up in 1978, indicating that forestry marketization can indeed promote the continuous growth of forestry economy. During the period of 1978-1992, there was no significant causal relationship between forestry marketization and forestry economic growth. This is because the Chinese socialist market 


\begin{tabular}{|c|c|c|c|c|c|}
\hline $\mathrm{H}_{0}$ & $\begin{array}{l}1978- \\
2016\end{array}$ & $\begin{array}{l}1978- \\
1992\end{array}$ & $\begin{array}{l}1993- \\
2002\end{array}$ & $\begin{array}{l}2003- \\
2016\end{array}$ & $\begin{array}{l}\text { Impacl on } \\
\text { marketization }\end{array}$ \\
\hline $\begin{array}{l}\text { Forestry marketization is not the Granger cause of forestry } \\
\text { economic growth }\end{array}$ & Reject & Accept & Reject & Reject & \\
\hline$p$-value & 0.0269 & 0.5962 & 0.0778 & 0.0269 & \\
\hline $\begin{array}{l}\text { Forestry economic growth is not the Granger cause of } \\
\text { forestry marketization }\end{array}$ & Accept & Reject & Accept & Accept & \\
\hline$p$-value & 0.2933 & 0.0390 & 0.7867 & 0.2933 & \\
\hline $\begin{array}{l}\text { The marketization of forestry factors is not the Granger cause } \\
\text { of forestry economic growth }\end{array}$ & Reject & Reject & Reject & Reject & \\
\hline$p$-value & 0.0727 & 0.0663 & 0.0571 & 0.0267 & \\
\hline $\begin{array}{l}\text { Forestry economic growth is not the Granger reason for the } \\
\text { marketization of forestry elements }\end{array}$ & Accept & Reject & Accept & Accept & \\
\hline$p$-value & 0.1549 & 0.0507 & 0.7978 & 0.1549 & \\
\hline $\begin{array}{l}\text { The marketization of forestry production is not the Granger } \\
\text { cause of forestry economic growth }\end{array}$ & Reject & Accept & Accept & Reject & \\
\hline$p$-value & 0.0420 & 0.8712 & 0.3315 & 0.0001 & \\
\hline $\begin{array}{l}\text { Forestry economic growth is not the Granger reason for the } \\
\text { marketization of forestry production }\end{array}$ & Accept & Reject & Reject & Accept & \\
\hline$p$-value & 0.1993 & 0.0995 & 0.0580 & 0.4420 & \\
\hline $\begin{array}{l}\text { The marketization of forestry products is not the Granger } \\
\text { cause of forestry economic growth }\end{array}$ & Reject & Reject & Reject & Reject & \\
\hline$p$-value & 0.0001 & 0.0422 & 0.0566 & 0.0193 & \\
\hline \multirow{2}{*}{$\begin{array}{l}\text { Forestry economic growth is not the Granger reason for the } \\
\text { marketization of forest products } \\
p \text {-value }\end{array}$} & Accept & Accept & Accept & Reject & \\
\hline & 0.0276 & 0.3273 & 0.4876 & 0.0276 & $\begin{array}{r}\text { Table } 8 . \\
\text { Granger test results }\end{array}$ \\
\hline
\end{tabular}

economic system was not yet built in 1978, and the basic framework of the system was established in 1993. Since then, forestry marketization has also been deepening, with significant Granger causality relationship with the forestry economic growth. In the period of 1978-2002, forestry economic growth was the Granger cause of forestry marketization. Since the reform and opening up, China's economy has developed rapidly, and forestry is also developing continuously. Various funds, labor, technology and other factors were drove to continuously invest on forest industry. Especially after China's accession to the WTO in 2001, foreign trade continued to increase and promoted the process of forestry marketization.

Based on the above analysis, we can know that specifically analyzing the Granger causality from three dimensions, the marketization of forestry factors, the forestry production and the forestry products are all Granger reasons for the forestry economic growth. In addition, during the period of 1978-1992, the marketization of forestry production were not the Granger reasons for the growth of forestry economy. On the contrary, forestry economic growth is the Granger cause of forestry marketization. The reason is similar to the above analysis. At the beginning of reform and opening up, China's marketization system has not been established, but in the process of economic development, forest products' prices and the trades are gradually released, state control is reduced. Especially in forestry production and management, it is mainly state-owned forest farms and other state-owned enterprises that dominate the production.

\section{Conclusions and implications}

\subsection{Conclusions}

The measurement system of China's forestry marketization indicators is creatively constructed from three dimensions, including forestry factor marketization, forestry 
FER

2,1

58

production marketization and forestry products marketization. Then, the statistical data from 1978 to 2016 are used to measure the status of forestry marketization in China. The research shows that China's forestry marketization already has made obvious achievements in the process of the reform on marketization. At the same time, China's forestry marketization process is needed to be further promoted in an all-round way, and marketsupporting reforms are needed to be further explored. In addition, the role of forestry marketization in forestry economic growth is analyzed by constructing the Cobb-Douglas production function and establishing regression equations. The results showed that forestry marketization was indeed an important driving force for China's forestry economic growth. And, forestry capital investment, forest land investment and forestry science and technology progress also play important roles in promoting China's forestry economic growth.

\subsection{Implications}

In the 40 years of reform and opening up, China's forestry marketization has achieved brilliant achievements. In the process of establishing and perfecting the marketization system, the forestry economy tended to obvious grow. In the process of market-oriented reform, the forestry economy has been continuing to develop in a healthy and stable manner. China's marketization not only absorbs the idea of free decentralization of the western market economy system, but also moderately integrates the characteristics of the centralized management of China's traditional public economy. So, it is a road of mixed marketization reform with Chinese characteristics. China's forestry marketization reform and development model provides an important reference sample for the world, especially for other developing countries. Through summarizing the process of China's forestry marketization, the following implications could be drawn for other countries: (1) forestry marketization reform should be promoted step by step. Marketization process could be orderly concluded as follows: from understanding marketization, accepting marketization, cultivating marketization, establishing marketization and deepening and improving marketization. (2) The market mechanism through reform and opening up and deepening supporting reforms should be adhered. Forest market management system in which multiple entities participate together should be built by deepening the market elemental trading systems, production management organization systems and product market-free sale systems. The market management systems should be focused on building fair market competition systems and playing the important role of market mechanisms in resource allocation and resource efficiency. (3) The relationship between the government and the market should be dynamically coordinated. The government should manage within jurisdiction. Government's direct intervention should be reduced in forestry production and management. The government should reduce the issuances of administrative orders and give the business entities more autonomy decentralization and fair empowerment. Meanwhile, the government should also encourage the forest owners to make rational management behavior. the market failure takes place, it should make full use of the regulation ability of government. (4) Both domestic and foreign markets should be developed at the same time. China not only paid attention to the domestic forestry factors market and forestry consumer market, but also attached importance to the development of foreign forestry resource market and forest product market. In addition, China also put more emphasis on the effective connection and benign interaction between the two markets. (5) Forestry state-owned economy, private economy and mixed economy should be coordinated for development. Forestry market economy should be activated by attaching importance to property rights reform and taking collective forest rights reform and state-owned forest rights reform as a breakthrough. Forestry private and mix ownership enterprises should be actively supported while attaching importance to state-owned forestry economy by advocating the cultivation of new forestry management entities, innovating economic development models such as under-forest economy, forest 
health and forestry industry integration. It is unwilling to see that the areas of the forest have declined about 3,999 ha between 1990 and 2015, which is worth noticing (FAO, 2015). And, forestry marketization is a significant component in construction of forestry development, and it is also a long-period process to push with diverse problems. Promoting forestry marketization can improve economic development and household livelihood, which can release the burden of deforestation. Since 1978, China has stepped out of the road of forestry marketization accompanied by the development of forestry economic growth with Chinese characteristics. At present, China's forestry marketization will be still deepening. In the future, its impact on forestry economic growth is expected by the world.

\section{References}

Bennett, J., Estrin, S. and Urga, G. (2007), "Methods of rivatization and economic growth in transition economies", Economics of Transition, Vol. 15 No. 4, pp. 661-683.

Cai, H. and Treisman, D. (2006), "Did government decentralization cause China's economic miracle?", World Politics, Vol. 4 No. 58, pp. 505-535.

Chang, X. and Gao, M. (1998), "The promotion degree and development ideas of China's national economy marketization”, Economic Research Journal, Vol. 11, pp. 49-56.

Chen, Z. and Chen, S. (1999), "Agricultural marketization process measurement in China”, Economist, Vol. 3, pp. 110-118.

De Melo, M., Denizer, C., Gelb, A. and Tenev, S. (2001), "Circumstance and choice: the role of initial conditions and policies in transition economies", The World Bank Economic Review, Vol. 15 No. 2, pp. 1-31.

Du, L. (2009), A Measurement of Forestry Market-Oriented Indicators, Method and Empirical Study, Jiangxi University of Finance and Economics, Jiangxi.

Fan, Zh. (2017), "The effect of forestry economic growth in the process of forestry marketization", Economic Research Guide, pp. 29-39.

Fan, G., Wang, X., Zhang, L. and Zhu, H. (2003), "Analysis on the new fluctuation mode of China economy development”, Economic Research Journal, Vol. 3, pp. 9-18.

Fan, G., Wang, X. and Ma, G. (2011), "Contribution of marketization to China's economic growth", Economic Research Journal, Vol. 9, pp. 4-16.

FAO/UN (2015), Global Forest Resources Assessment 2015: How Are The World's Forests Changing?, FAO, Rome.

Gerard, R. (2004), Transition and Economics, The Peking University Press, Beijing.

Hyde, W.F. and Yin, R. (2019), "40 Years of China's forest reforms: summary and outlook”, Forest Policy and Economics, Vol. 98, pp. 90-95.

Iradian, G. (2009), "What Explains the rapid growth in transition economies?", Economics of Transition, Vol. 11 No. 4, pp. 649-669.

Ke, S., Chen, Z. and Zhao, T. (2014), "Factors influencing China's forest economic growth based on grey correlation model", Journal of Agro-Forestry Economics and Management, Vol. 13 No. 03, pp. 281-290.

Kong, F. and Du, L. (2010), "Theory of forestry market-oriented processing estimation and empirical analysis on the 15 provinces (regions) in China”, Scientia Silvae Sinicae, Vol. 10, pp. 135-143.

Kong, F. and Liao, W. (2013), "Forestry economic growth effect of China's forestry marketization process", Chinese Rural Economy, Vol. 9, pp. 87-96.

Liao, W. and Zhang, G. (2014), "Effects of China's forestry marketization on farmers' revenue from 2002 to 2011", Forestry Economics, Vol. 9, pp. 93-97.

Lin, Y., Cai, F. and Li, Z. (1993), “On the progressive road of China's economic reform”, Economic Research Journal, Vol. 9, pp. 3-11.
Impact of
marketization
process 
FER

2,1

60

Lu, C. and Zhu, D. (2016), "How does market-oriented reform affect long-term economic growth? analysis based on market potential perspective”, Management World, Vol. 02, pp. 32-44.

Merlevede, B. (2003), "Reform reversals and output growth in transition economies", Economics of Transition, Vol. 11 No. 4, pp. 649-669.

North, D. (1990), Institutions, Institutional Change and Economic Performance, The University Press, Cambridge.

Selowsky, M. and Martin, R. (1997), "Policy performance and output growth in the transition economics”, American Economic Review, Vol. 87 No. 2, pp. 349-353.

Shu, X., Gao, Y., Zhang, Y. and Yang, Y. (2015), "Study on the coupling relationship and coordinative development between tourism industry and eco-civilization city. China population”, Resources and Environment, Vol. 03, pp. 82-90.

Song, L (2014), "The forestry by international financial organizations loan for 30 years", Forestry Economics, Vol. 8, pp. 7-18.

Sun, X. and Li, M. (2014), "Differences in the marketization process of regions in our country: 20012011”, Reform, Vol. 6, pp. 59-66.

Sun, Z., Liu, F. and Li, Z. (2005), "Market development, government influence and corporate debt maturity structure”, Economic Research Journal, Vol. 5, pp. 52-63.

Wang, W. and Fan, H. (2007), "Empirical analysis of Chinese marketization contribution to economy growth”, China Industrial Economy, Vol. 09, pp. 48-54.

Wang, L. and Tan, D. (2005), "EBA model for relationship between economic growth and marketization level in China”, Journal of Southwest Jiaotong University, Vol. 40 No. 6, pp. 821-824.

Wu, L. (2018), “The contribution of China's marketization process to economic growth”, China Market, Vol. 10, pp. 60-65.

$\mathrm{Xu}, \mathrm{W}$. (2012), “On the problems and countermeasures faced by the reform of forestry marketization”, Heilongjiang Science and Technology Information, Vol. 16, pp. 225-227.

$\mathrm{Xu}, \mathrm{J}$. and Hyde, W.F. (2019), "China's second round of forest reforms: observations for China and implications globally”, Forest Policy and Economics, Vol. 98, pp. 19-29.

Xu, J., Deininger, K. and Hyde, W.F. (2019), China's Collective Forests: Global Lessons from Tenure Reform. Forest Tenure Reform in China, World Bank, Washington.

Zeng, X. (2003), "A new method on measurement of marketization_— under the view of global trade”, Finance and Trade Economics, Vol. 8, pp. 12-18.

Zhou, C., Feng, X. and Tang, R. (2016), "Analysis and forecast of coupling coordination development among the regional economy-ecological environment-tourism industry - a case study of provinces along the yangtze economic zone”, Economic Geography, Vol. 3, pp. 186-193.

Zhuang, S (2016), "The effect of forestry economic growth in the process of China's forestry marketization”, Shanxi Agricultural Economics, Vol. 18, p. 27.

\section{Further reading}

$\mathrm{Lu}, \mathrm{Z}$. and Hu, A. (1993), "The influence of marketization reform on China's economic operation", Economic Research Journal, Vol. 12, pp. 49-55.

\section{Corresponding author}

Shuifa Ke can be contacted at: keshuifa@163.com

For instructions on how to order reprints of this article, please visit our website:

www.emeraldgrouppublishing.com/licensing/reprints.htm

Or contact us for further details: permissions@emeraldinsight.com 